\title{
IMPLEMENTING DUBBING MUTED VIDEO IN SPEAKING CLASS
}

\author{
Putra, I. G. Y. A. \\ English Education Department, Ganesha University of Education \\ gdeyamadita@gmail.com \\ Padmadewi, N. N. \\ English Education Department, Ganesha University of Education \\ nympadmadewi@undiksha.ac.id \\ Suprianti, G.A.P \\ English Education Department, Ganesha University of Education \\ gap.suprianti@undiksha.ac.id
}

\begin{abstract}
This Experimental study was aimed at finding out the significant effect of Dubbing Muted Video on the speaking achievement of the eleventh grade students of SMK N 3 Singaraja in academic year of 2015/2016. Post-test only control group was the design of this study. The population of this study was all eleventh grade students of SMK N 3 Singaraja consisted of 108 students and distributed into 4 classes. Cluster random sampling technique was used in order to define which class selected as control group and which class selected as experimental group. Class IX TKJ 2 class was selected as the experimental group, then it was taught by using Dubbing Muted Video method. Meanwhile, Class IX TKJ 1 was selected as the control group, then it was taught by PPP teaching method. Class IX TKJ 2 consisted of 28 students and Class IX TKJ 1 consisted of 27 students. The result of data analysis showed that the students who were taught by Dubbing Muted Video performed better than those who were taught by PPP teaching method. The descriptive statistic analysis result of the students' speaking achievement showed that the mean score of control group was 77.85, while the experiment group was 83.11. The result of t-test analysis of the $t_{\text {obs }} w a s 2.054$ it was higher than the value of the $t_{c v}$ at 2.005 It means that the there is significant effect of Dubbing Muted Video on the students' speaking achievement.
\end{abstract}

Keywords: Speaking Achievement, Dubbing Muted Video

\section{INTRODUCTION}

As social being, human must have four language skills to interact with other namely listening, speaking, writing, and reading. To be able to master a language, those skills must be mastered and that is why in each country the study about language is implemented. English in specific is standard international language in which every country includes its subject of study in their school curriculum.

According to Underhill (1987:96), speaking is a complex skill which needs understanding and mastering structure of the components of language proficiency such as: pronunciation, grammar (structure), and vocabulary. Therefore, the success of conducting speaking always depends on mastery of those components. If the components have been mastered well, the speaker will be successful in speaking. However, if the speaker does not master those components, the speaker will break the communication and the message that is transferred will be difficult to understand.

The mastery of speaking influence how human interacts with other. When one of the component is not mastered by the speaker the communication will be broken and the meaning and the information will not be able to reach the listener. Furthermore, if the listener does not understand and get the information there will be a miscommunication where the listener may interpret what the speaker intended to tell with other false information.

Human interaction is mainly by talking to each other that's why speaking is so much important just as Byrne (1986) states that the main goal of teaching productive skill of language is to conditioning the students in order to make them familiar and fluent in using oral language. This shows 
how much important oral language is to be learned. Also, this shows the importance of intention of teaching spoken language in classroom as oral language to make students able to express their ideas in target language. Another researcher, brown and yule (1983) say that any kind of human interaction such as in public places: bus, train, and a meeting are intently to conduct conversation or talk. From that the main purpose is to create a meaningful and understandable communication to rely their message between the speaker and listener.

How efficient and effective the transfer of information between speaker and listener are affected by several reasons. According to Hughes (1989) there are several aspects that concern how effective the message could be received by the listener namely; fluency, accuracy, structure, vocabulary and content of speech. The listener won't be able to interpret what the speaker wants to talk about if the speaker stutters a lot which slows down the speaker talking speed and makes the message hard to understand. With bad accuracy of choosing the right words also could make the conversation even worse. The intonation and pronunciation when the speaker speaks might also alter the real message into another message that's why accuracy in speaking is really important. How the speaker construct the message also important. Structure is like the system of the language since it is one of the elements that concern the target language. Structures is like a set of rules that the speakers need to obey to make the message meaningful and easy to understand, which consist of how to form and pronounce the phrases and sentences. Vocabulary is really important in producing a foreign language.

To make communication more effective the speaker needs to master the structures and words of the target language. Without the knowing of words of a language a person could never talk in that language that's why it is important to increase word bank of the target language if the speaker wants to learn the language. Message could also hard to understand if the speaker doesn't really have the content of what he/she is trying to tell. This content of speech is pretty much the idea, feeling, and thoughts refer to the kinds of mental process that occur during the act of formulating a speech or talk. Therefore, it is necessary for the students to express appropriate speech that is relevant to the topic. Also when the speaker relay the thoughts, ideas or feeling through speaking it is expected that he/she are able to produce logical thoughts and express it orally based on the topic being discussed. Hence there might be several seconds or minutes before someone start talking because they might still be thinking what their content of speech is, what is their ideas, feelings or thoughts. So, they are going to have a relaxed conversation with the listener and vice versa, which also enhance the consistency of the flow that will make them able to understand each other.

\section{METHODS}

Research design of this study was posttest only control group design. In this type of research design, it only considered post-test score in data analysis, the score that was used to find out the normality test and homogeneity of variance was students' score from previous semester (Summative score).

According to Fraenkel and Wallen. 1993, population is the group of interest to the researcher, the group to whom the researcher would like to generalize the results of the study. The eleventh-grade students of SMK Negeri 3 Singaraja in the academic year 2015/2016 are select as the population. All individuals in this population shared at least one characteristic in common, that is they are in the same grade. Total numbers of the students in this population are 108 students, which divide into 4 . In this study, cluster random sampling technique is applied to obtain the sample of the study. After using cluster random sampling technique there are two classes was chosen. One as experimental group and one as control group. The experimental group was XI TKJ 2 and the control group was XI TKJ 1.

A good instrument must include two important points, namely; Validity and Reliability. Validity is the extent to which the tests measure what they are expected to be measured. In the other words validity is the degree to which the study accurately reflects or assesses the specific concept that researcher is attempting to measure. Reliability is the way to measure the stability of the test. In the other words, reliability refers to the consistency of the score or answer provided by the instruments. It is the extent to which it would give the same result under repeated usage. Ebel Formula was used to examine students' test. 

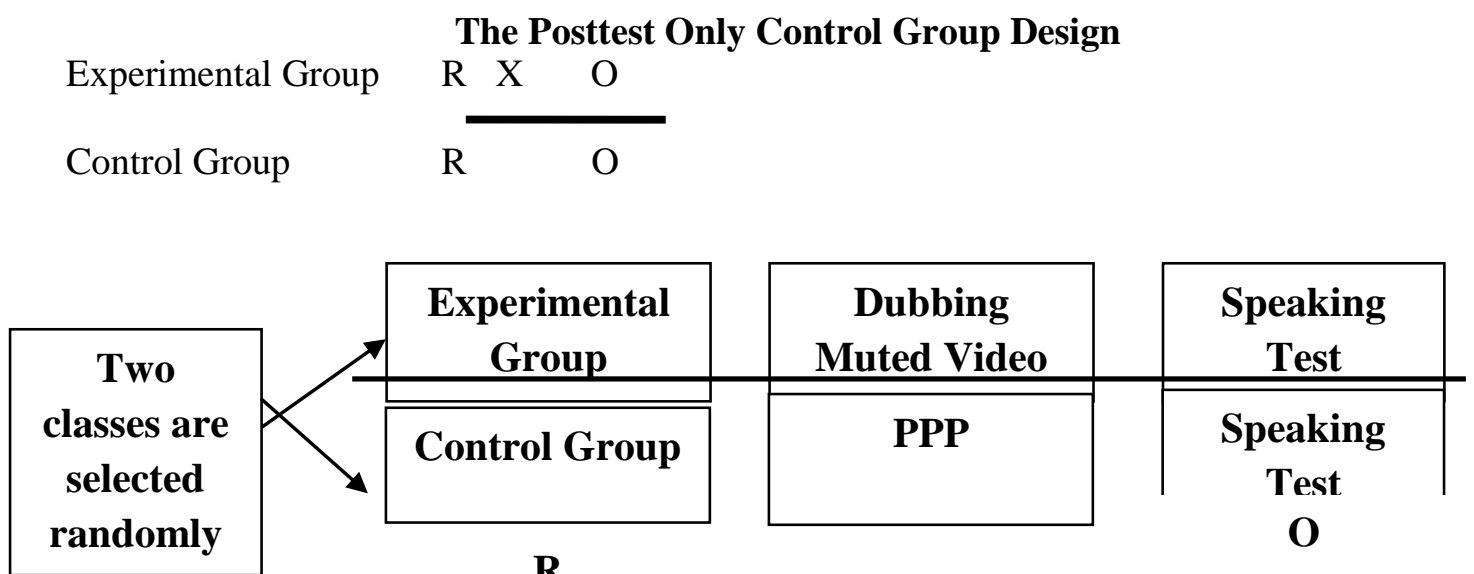

Random

Posttest

Assignment

Figure 1 Research Design of Post-Test Only Control Group

Method and technique of data analysis used in this study was Descriptive analysis and Inferential analysis. Descriptive analysis is the process of describing scores of the obtained data. The descriptive statistic analyzes data covers the calculation of mean score, mode, median, standard deviation and variance. Inferential analysis is used to determine whether or not the difference of the mean score of the two samples was significant. As for data processing researcher has done normality and homogeneity test continued by t-test by using Statistical Product and Service Solution (SPSS) version 16.

\section{FINDING AND DISCUSSION}

In this research, the researcher conducted a normality test before the treatment was conducted. It was used to determine whether the data were having normal distribution or not.

Table 1 The Result of Normality Test Before Treatment

Tests of Normality

\begin{tabular}{|c|c|c|c|c|c|c|}
\hline & \multicolumn{3}{|c|}{ Kolmogorov-Smirnov $^{\mathrm{a}}$} & \multicolumn{3}{|c|}{ Shapiro-Wilk } \\
\hline & Statistic & $\mathrm{df}$ & Sig. & Statistic & df & Sig. \\
\hline Control & .159 & 27 & .076 & .942 & 27 & .139 \\
\hline Experimental & .165 & 27 & .058 & .930 & 27 & .071 \\
\hline
\end{tabular}

a. Lilliefors Significance Correction

The result of the normality test in the table 1 showed that the significance value (Sig.) of each group had exceed the value of 0.05 . as the table showed above the Sig. value of the normality test reached by Control Class was .139 and the Sig. value of the experimental class was 0.71 . That result meant that the data obtained in this study was already normally distributed.

The researcher also conducted the homogeneity test before the treatment was conducted. In testing homogeneity of the variance.

Table 2 The Result of Homogeneity Test Before Treatment

Test of Homogeneity of Variance

\begin{tabular}{llrrrrr}
\hline & & Levene Statistic & df1 & df2 & \multicolumn{1}{c}{ Sig. } \\
\hline \multirow{2}{*}{ Score } & Based on Mean & .077 & 1 & 53 & .783 \\
& Based on Median & .051 & & 1 & 53 & .823
\end{tabular}


Based on Median and with adjusted df

Based on trimmed mean
1

The result of the data above showed that the significance value (Sig.) of each group had exceed the value of 0.05 . the Sig value was .783. considering the result, this meant that the variances between group were already homogenous.

Descriptive analysis is the process of describing scores of the obtained data. The descriptive statistic analyzes data covers the calculation of mean score, mode, median, standard deviation and variance

Table 3 The Distribution Analysis of Data Measured in Post-Test

\begin{tabular}{lllllll}
\hline Post test & Mean & Median & Mode & Range & Variance & $\begin{array}{l}\text { Standard } \\
\text { deviation }\end{array}$ \\
\hline $\begin{array}{c}\text { Experimental } \\
\text { group }\end{array}$ & 83.11 & 84 & 86 & 34 & 71.179 & 8.43679 \\
Control group & 77.85 & 78 & 82 & 38 & 99.054 & 9.95259 \\
\hline
\end{tabular}

The inferential analysis provides information about the significant effect of Dubbing Muted Video on students' speaking achievement of both groups. The data was analyzed using t-test in which the data should have normal distribution and homogeneity of variance first.

Table 4 The Result of Normality Test After Treatment

\begin{tabular}{|c|c|c|c|c|c|c|}
\hline \multicolumn{7}{|c|}{ Tests of Normality } \\
\hline & \multicolumn{3}{|c|}{ Kolmogorov-Smirnov ${ }^{\mathrm{a}}$} & \multicolumn{3}{|c|}{ Shapiro-Wilk } \\
\hline & Statistic & df & Sig. & Statistic & df & Sig. \\
\hline Control & .095 & 27 & $.200^{\circ}$ & .977 & 27 & .781 \\
\hline Experimental & .134 & 27 & $.200^{*}$ & .965 & 27 & .470 \\
\hline
\end{tabular}

The result of normality test on the table above indicated that the Sig (significance value) of each group has exceed the value of 0.05 . The significance value reached by experimental group was .200 and control group was .200 . Those result means that the data obtained in this study was already normally distributed.

Table 5 The Result of Homogeneity Test After Treatment

\begin{tabular}{llrrrr}
\multicolumn{2}{c}{ Test of Homogeneity of Variance } & & \\
\hline & Levene Statistic & df1 & df2 & Sig. \\
\hline Score & Based on Mean & 2.104 & 1 & 53 & .153 \\
& Based on Median & 2.088 & 1 & 53 & .154 \\
& Based on Median and with & 2.088 & 1 & 52.945 & .154 \\
adjusted df & & & & 53 \\
& Based on trimmed mean & 2.099 & 1 & & .153 \\
\hline
\end{tabular}


The result above about the homogeneity test after post test showed that the Sig. value (significance value) had exceed the value of 0.05 . The significance value based on mean was .153 . considering the result, it means that the variances between the two groups were already homogeneous.

Hypothesis Testing (T-test)

To know the effect of Dubbing Muted Video on Speaking achievement of Eleventh grade students, hypothesis testing was conducted. Hypotheses that were tested were:

$\mathrm{H}_{0}: \mu=\mu_{0}$ there is no significant effect of Dubbing Muted Video on the speaking achievement of the eleventh grade students of SMK N 3 Singaraja.

$\mathrm{H}_{1}: \mu>\mu_{0}$ there is significant effect of Dubbing Muted Video on the speaking achievement of the eleventh grade students of SMK N 3 Singaraja.

The data was analyzed using t-test after having normality and homogeneity tested to find out whether or not there is a significant effect of Dubbing Muted Video on studdents' speaking achievement. The result of t-test analysis can be seen below.

Table 6 The Result Of T-Test

\begin{tabular}{|c|c|c|c|c|c|c|c|c|c|c|}
\hline \multicolumn{11}{|c|}{ Independent Samples Test } \\
\hline & & \multicolumn{2}{|c|}{$\begin{array}{l}\text { Levene's Test } \\
\text { for Equality of } \\
\text { Variances }\end{array}$} & \multicolumn{7}{|c|}{ t-test for Equality of Means } \\
\hline & & & Sig. & \multirow[t]{2}{*}{$\mathrm{T}$} & \multirow[t]{2}{*}{ df } & \multirow[t]{2}{*}{$\begin{array}{l}\text { Sig. } \\
(2- \\
\text { tailed })\end{array}$} & \multirow[t]{2}{*}{$\begin{array}{c}\text { Mean } \\
\text { Difference }\end{array}$} & \multirow[t]{2}{*}{$\begin{array}{l}\text { Std. Error } \\
\text { Difference }\end{array}$} & \multicolumn{2}{|c|}{$\begin{array}{l}95 \% \text { Confidence } \\
\text { Interval of the } \\
\text { Difference }\end{array}$} \\
\hline & & & & & & & & & Lower & Upper \\
\hline \multirow[t]{2}{*}{ Score } & $\begin{array}{l}\text { Equal } \\
\text { variances } \\
\text { assumed }\end{array}$ & 2.104 & .153 & 2.054 & 53 & .045 & 5.07672 & 2.47186 & .11879 & 10.03465 \\
\hline & $\begin{array}{l}\text { Equal } \\
\text { variances not } \\
\text { assumed }\end{array}$ & & & 2.047 & 50.721 & .046 & 5.07672 & 2.47991 & .09742 & 10.05602 \\
\hline
\end{tabular}

Table above showed that the significance (2-tailed) was 0.045 . it was lower than 0.05 . then the value of $t_{\text {observed }}$ was 2.054 and the df was 53, it means that the $t_{\text {critical value }}$ is 2.005 . it means that the value of

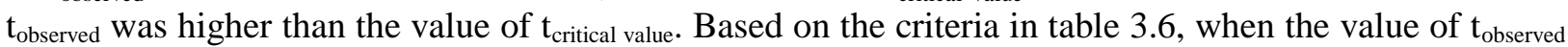
is higher than the value of $t_{\text {criticalvalue }}$ the alternative hypothesis $\left(\mathrm{H}_{1}\right)$ " There is significant effect of Dubbing Muted Video on speaking achievement of the eleventh grade students in SMK N 3singaraja" was accepted. And the null hypothesis $\left(\mathrm{H}_{0}\right)$ "there is no significant effect of Dubbing Muted Video on speaking achievement of the eleventh grade students in SMK N 3 Singaraja" was rejected.

\section{CONCLUSION AND SUGGESTION}

The result of the findings and discussion of this study that can be seen in the previous chapter shows that there is a significant difference between the students taught by using Dubbing Muted Video. Students who were taught by using Dubbing Muted Video obtained better speaking score than who were taught by using PPP technique. It could be seen from the result of the mean score. The mean score of the experimental group was 83.11, while control group was 77,85. Moreover the result of the T-test showed that the value of tobs was 2.054 and the value of tcv was 2.005 (in $\mathrm{df}=53$ ). It means that the value of tobs was higher than tcv. Then it can be concluded that there was significant effect of Dubbing Muted Video on students speaking achievement of eleventh grade students in SMK N 3 Singaraja.

For English teacher, $\mathrm{t}$ is suggested that teacher used Dubbing Muted Video in the classroom since it made students more active in the classroom and practice more to speak with each other. There were some factor need to be considered by the teacher when trying to use Dubbing Muted Video in the class: (1) teacher need to be clear in explaining the steps on how they will dub the video since students might having difficulties when they try it the first time; and (2) while they are doing their work, they might made noise and disturb other students in the process. Teacher need to take control on that situation to make the learning process better. For other researcher, it is recommended that other researcher who is 
interested in doing similar research to do in different level of education and to uncover more advantages that Dubbing Muted Video could deliver.

\section{REFERENCES}

Brown, G \& Yule, G (1983). Discourse Analysis. Cambridge University Press

Byrne, D. (1986). Teaching Oral English. Longman House.

Fraenkel, J. R., \&Wallen, N. E. (1993) How to design and evaluate research in education $\left(2^{\text {nd }} e d\right)$. McGraw-Hill

Hughes, A. (2002). Testing for language Teacher, Second Edition, United Kingdom: Cambridge University Press.

Underhill, N (1987). Testing Spoken Language: A Hand Book of Oral Testing Techniques. Cambridge University Press. 